\title{
Introduction to special issue on the Proceedings of the 3rd International Urolithiasis Research Symposium held in Indianapolis
}

\author{
Andrew P. Evan · James E. Lingeman • \\ James A. McAteer $\cdot$ James C. Williams Jr.
}

Received: 2 July 2010/Accepted: 6 July 2010/Published online: 22 July 2010

(C) Springer-Verlag 2010

\section{Introduction}

The 3rd International Urolithiasis Research Symposium, put on by the International Kidney Stone Institute, was held in Indianapolis, IN, USA, on 3-4 December 2009. The symposium included special sessions on nephrocalcinosis, pediatric stone disease, hypercalciuria and plaque, and stone analysis. There were additionally two sessions on shock wave lithotripsy, looking at renal injury and the mechanisms underlying tissue damage by shock waves. The symposium also included two live stone surgeries that allowed participants to see two distinctly different pathologies on live video, with added commentary by experts in the auditorium showing biopsy results from similar patients.

The theme running throughout the symposium was that we have much to learn about the pathologies underlying the different forms of stone disease. For too long, these pathologies have been lumped together, but it is quite clear from recent studies in patients that trying to study 'stone disease' in a 'calcium stone' patient group that includes, for example, both idiopathic calcium oxalate stone formers and patients who form calcium oxalate stones as a consequence of bowel disease is very much a study of apples and oranges. Such confusion has clouded some work in the past. In contrast, new clarity in this field promises to allow an acceleration of study of the diseases that result in urinary calculi.

Included in this installment of papers from the symposium is a stunning and new analysis of patient data by Fred Coe and his colleagues, which sheds further light on the distinctions among different groups of stone formers. Some excellent reviews are also here, including an insightful summary of cell-crystal interactions by Benjamin Vervaet and co-workers. Several papers of original laboratory research are included, and in this category is Laurie Gower and colleagues' summary of work showing that many of the mineral forms in stones are apparently determined by non-mineral molecules, pointing to specific roles for biomolecules in the formation of urinary stones. This last paper was honored with the Best Basic Science Poster Award at the symposium.

The next International urolithiasis research symposium is scheduled for 16-17 June 2011, again in Indianapolis. We look forward to seeing you there.
Proceedings paper from the 3rd International Urolithiasis Research Symposium, Indianapolis, IN, USA, 3-4 December 2009.

A. P. Evan · J. E. Lingeman · J. A. McAteer ·

J. C. Williams Jr. (\)

Indiana University School of Medicine,

Indianapolis, IN, USA

e-mail: jwillia3@iupui.edu 